Kumawula, Vol. 1, No.3, Desember 2018, Hal 202 - 218 DOI:http://10.24198/kumawula.v1i3. 22676

ISSN 2620-844X (online)

Tersedia online di http://jurnal.unpad.ac.id/kumawula/index

\title{
PERAN PEKERJA SOSIAL DALAM ADOPSI ANAK
}

\author{
Yolanda Triana Siregar ${ }^{1}$, Meilanny Budiarti Santoso ${ }^{2}$ \\ ${ }^{1,2}$ Fakultas Ilmu Sosial dan Ilmu Politik, Universitas Padjadjaran \\ 11yolandatrianasiregar@gmail.com, 2meilannybudiarti13@gmail.com
}

\begin{abstract}
ABSTRAK
Artikel ini bermaksud memaparkan berbagai peran pekerja sosial dalam proses adopsi anak, khususnya di Indonesia. Adopsi merupakan salah satu upaya yang dilakukan pasangan suami istri untuk dapat memiliki kehadiran sosok anak di keluarga mereka. Di Indonesia, proses pengajuan dan prosedur adopsi telah jelas diatur dalam beberapa undang-undang dan ketetapan pemerintah yang berlaku. Namun dalam pelaksanaannya, masih ada berbagai permasalahan adopsi yang terjadi di Indonesia. Tujuan dari penulisan artikel ini adalah untuk mendeskripsikan dan mengeksplorasi praktik adopsi di Indonesia dan peran pekerja sosial dalam upaya menanganinya. Metode yang digunakan dalam penulisan artikel ini adalah metode studi literatur. Hasil dari kajian yang dilakukan adalah diperlukannya upaya peningkatan informasi mengenai adopsi kepada masyarakat melalui kemudahan aksesibilitas layanan adopsi di setiap otoritas lokal. Hal ini dapat dicapai melalui integrasi yang baik antara pemerintah, lembaga sosial anak, pengadilan, dan pekerja sosial. Selain itu, pelayanan adopsi yang diberikan harus dipastikan sampai pada tahap pengawasan, pendampingan, dan penguatan terhadap pengasuhan calon orang tua angkat untuk menjamin terpenuhinya prinsip kepentingan terbaik bagi anak dan upaya pemenuhan hak anak di masa mendatang.
\end{abstract}

Kata Kunci: adopsi anak, peran pekerja sosial, kepentingan terbaik bagi anak

\begin{abstract}
This article intends to describe the various roles of social workers in the process of adoption of children, especially in Indonesia. Adoption is an attempt by a married couple to be able to have a child in their family. In Indonesia, the submission process and adoption procedure are clearly regulated in several applicable government laws and regulations. But in its implementation, there are still various adoption problems that occur in Indonesia. The purpose of writing this article is to describe and explore adoption practices in Indonesia and the role of social workers in addressing them. The method used in writing this article is the method of literature study. The results of the study carried out is the need for efforts to increase information about adoption to the community through the ease of accessibility of adoption services in each local authority. This can be achieved through good integration between government, children's social institutions, the courts and social workers. In addition, the adoption services provided must be ensured to the stage of supervision, assistance, and strengthening of the care of prospective adoptive parents to ensure the fulfillment of the best interests of the child and efforts to fulfill children's rights in the future.
\end{abstract}

Keywords: child adoption, the role of social workers, the best interests of the child

\section{PENDAHULUAN}

Sebagai sebuah pengantar situasi praktik adopsi anak yang terjadi di Indonesia, dengan 
seting kasus adopsi anak dengan orang tua kandung yang merupakan keluarga miskin sehingga memberikan anaknya untuk diadopsi oleh keluarga lain sebagai calon orang tua angkat dari anaknya. Setelah dalam proses adopsi dan masa pengasuhan selama enam bulan sebagai masa percobaan, orang tua kandung masih ingin menengok anaknya dalam frekuensi yang sering, sehingga calon orang tua angkat merasa tidak berkenan karena dianggap mengganggu proses adopsi yang sedang dilakukannya. Dalam situasi demikian, calon orang tua angkat menyampaikan keluhannya kepada pekerja sosial bahwa dirinya merasa dihalangi untuk dapat bertemu dengan anak kandungnya, sehingga merasa kecewa dan merasa calon orang tua angkat hendak merebut dan menghilangkan keberadaan mereka sebagai orang tua kandung dan calon anak angkat. Dalam situasi demikian, profesi pekerjaan sosial harus dapat memberikan pemahaman kepada kedua belah pihak (orang tua kandung dan calon orang tua angkat), sehingga pada akhirnya tidak terjadi konflik.

Berdasarkan gambaran situasi dalam kasus tersebut, dapat disimpulkan bahwa mayoritas pasangan suami isteri yang telah menikah, pasti menginginkan kehadiran anak di dalam keluarga mereka. Santoso et al. (2018) mengungkapkan beberapa alasan seseorang menginginkan menjadi orang tua yaitu: pertama, orang dewasa secara naluriah telah disiapkan dalam dirinya untuk merespon positif atas kehadiran bayi, hal ini seperti juga dikemukakan juga oleh Kringelbach et al. (2008) dan didukung oleh hasil penelitian Hotz (2008) yang menunjukkan bahwa pencitraan saraf dalam otak orang dewasa tertarik dengan bayi dan merespons secara positif ketika mereka melihat bayi. Kedua, adanya dorongan dan pengaruh yang kuat dari masyarakat untuk memiliki anak. Hoffman \& Manis (1979) menyatakan bahwa setelah seseorang menjadi dewasa, lebih dari pekerjaan atau pernikahan, masyarakat menjabarkan kedudukan sebagai orang tua sebagai tanda kematangan dan kedewasaan.

Akan tetapi, terkadang keinginan untuk memiliki anak tersebut tidak selalu dapat tercapai karena faktor lain, salah satu faktor penyebab utamanya adalah faktor biologis sang suami atau istri yang memang tidak memungkinkan untuk memiliki keturunan. Beberapa pasangan mungkin masih mengupayakan untuk dapat tetap memiliki keturunan melalui hasil darah daging mereka sendiri, sehingga seringkali pasangan suami isteri yang modern dan berkecukupan melupakan adanya cara yang lebih konvensional dan praktis untuk menghadirkan anak dalam keluarga, yaitu pengangkatan anak atau yang sering juga dikenal dengan istilah adopsi. Dalam melakukan adopsi, setiap orang memiliki motif dan alasan yang berbeda, baik itu untuk dirinya sendiri atau untuk mengangkat derajat anak yang bersangkutan. 
Namun, alasan melakukan adopsi tersebut harus memiliki hasil yang timbal balik antara pemenuhan alasan atau motivasi orang tua dan kebutuhan anak yang di adopsi. Beberapa alasan atau motif lain seseorang melakukan adopsi dalam Bakhtiar \& Yustiana (2017), antara lain:

1) Tidak adanya kehadiran anak dalaam keluarga, dan keinginan untuk memiliki anak mereka sendiri untuk menjaga di masa depan dan di masa tua;

2) Untuk mempertahankan ikatan pernikahan atau kebahagiaan keluarga;

3) Keyakinan bahwa jika kehadiran anak dapat memicu mereka untuk dapat memiliki anak kandung sendiri;

4) Rasa kepedulian terhadap anak-anak terlantar atau anak dengan orang tua yang tidak sanggup mempertahankan mereka;

5) Untuk menambah atau mendapatkan pekerjaan.

Pernyataan ini juga selaras dengan apa yang dikemukakan oleh M. Budiarto (dalam Alfaizi, 2016) bahwa motif pengangkatan anak secara umum antara lain adalah keinginan untuk mempunyai ank, adanya keinginan memiliki anak lagi, sebagai rasa belas kasihan terhadap anak terlantar, dan juga terhadap anak yatim piatu.

Situasi yang terjadi di Indonesia terkait peristiwa adopsi adalah bahwa belum adanya rekapan data secara valid dan pasti terkait dengan jumlah anak yang dapat di adopsi maupun jumlah anak yang telah di adopsi. Data statistik maupun data dari penelitian sebelumnya tidak ada yang memaparkan jumlah secara pasti terkait dengan peristiwa adopsi. Fakta ini menegaskan bahwa informasi mengenai adopsi di Indonesia masih sangat terbatas untuk dapat diakses oleh masyarakat.

Pemerintah dalam hal ini masih belum memfasilitasi masyarakat secara maksimal terkait dengan kebutuhan adopsi, walaupun sebenarnya ada prosedur jelas yang telah ditetapkan dan disahkan secara hukum melalui undang-undang atau kebijakan terkait dengan adopsi di Indonesia. Namun, kurangnya sosialisasi dan fasilitasi yang diberikan oleh pemerintah secara publik menjadikan banyak masyarakat (khususnya pasangan suami istri) yang tidak mengetahui prosedur adopsi yang sah secara hukum melalui pengadilan.

Berbeda halnya yang terjadi di Negara lain, seperti yang diungkapkan oleh Save the Children (2012), di beberapa Negara seperti Rwanda, Sri Lanka, Indonesia, dan Haiti memiliki kesamaan permasalahan mengenai bentuk fasilitas penitipan atau penampungan anak (biasanya mengacu pada panti asuhan atau lembaga lain), yaitu dalam satu tempat penitipan sudah tercampur antara anak yang masih memiliki anggota keluarga dengan anak yang sudah tidak memiliki anggota keluarga sama sekali, sehingga dapat di adopsi. Bentuk institusi seperti ini 
dapat merusak mekanisme di dalam komunitas pendukung anak yang sebenarnya masih dapat mendorong keluarga untuk menempatkan anak-anak mereka di dalam keluarga kandungnya menjadi melakukan tindakan menempatkan anak di dalam fasilitas tersebut.

Hal ini menjadi salah satu penyebab sulitnya menemukan data valid mengenai jumlah anak yang dapat di adopsi di Indonesia. Padahal setiap anak memiliki hak yang harus diperjuangkan jika anak masih memungkinkan untuk tetap dapat diasuh oleh orang tua kandungnya sendiri. Kemiskinan dan kurangnya sumber daya seharusnya tidak boleh menjadi alasan untuk memisahkan anak dari keluarganya (Save the Children, 2012). Sebab jika alasannya seperti itu, maka pilihan yang terbaik untuk dilakukan adalah dengan melakukan pemberdayaan terhadap keluarga tersebut agar dapat tetap mengasuh anak yang bersangkutan.

Walau di Indonesia data mengenai jumlah adopsi tidak ada, tetapi dinamika mengenai adopsi dapat dilihat melalui data di luar negeri. Menurut Adoption and Foster Care Analysis and Reporting System (AFCARS) di Amerika Serikat pada Agustus 2018, hampir 433.000 anak ada di tempat penampungan dan lebih dari 123.437 anak menanti untuk di adopsi setiap tahunnya. Angka ini adalah dua kali nya dari jumlah anak yang sebenarnya ada dan ditempatkan di penampungan anak (seperti panti asuhan). Lebih buruknya lagi, sekitar 20.000 anak di luar penampungan anak tidak teradopsi setiap tahunnya, menempatkan mereka pada risiko tinggi terhadap kondisi pengangguran, trafficking, menjadi tuna wisma, dan penahanan anak (Family Equality, 2019). Angka adopsi di Amerika Serikat juga sebenarnya tidak terlalu tinggi. Diperkirakan sekitar 4\% warga Amerika merupakan hasil adopsi (Olson \& DeFrain, 2006).

Setiap tahun puluhan ribu anak di adopsi dari satu negara ke negara lain, dengan mayoritas anak di adopsi dari negara berkembang ke negara maju (Save the Children, 2012). Walaupun selama 10 dekade sejak 2004 hingga 2014, jumlah adopsi internasional mengalami penurunan persentase yang signifikan (Zuhra, 2016). Di Negara Indonesia, adopsi juga banyak dilakukan. Menurut Yayasan Mijn Root, pada kurun waktu antara 1978-1983 ada sekitar 3.000 anak Indonesia yang di adopsi ke luar negeri. Ada juga anak yang di adopsi secara sah oleh sesama warga Indonesia, meskipun banyak anak yang di adopsi secara tidak sah (BBC News Indonesia, 2018). Banyaknya anak yang di adopsi secara tidak resmi tersebut diakibatkan juga oleh kurangnya sosialisasi prosedur adopsi melalui pengadilan. Dengan demikian, private adoption dan adopsi ilegal masih sering terjadi di Indonesia. Bahkan dikatakan sebanyak ratusan bayi yang baru lahir setiap tahunnya dapat diperdagangkan di pasar gelap yang menguntungkan di Indonesia, sebagian besar secara ilegal dijual kepada orang tua di luar negeri (Bachelard, 2013). 
Adopsi (adoptie atau adoption) menurut Williams, Sawyer, dan Wahlstrom (2007) adalah kegiatan saat pasangan keluarga dengan sengaja mengambil anak dari pasangan keluarga lain sebagai anaknya sendiri, biasanya diakibatkan karena orang tua kandung telah memutuskan untuk tidak lagi mengasuh anak tersebut atau anak-anak tersebut tidak lagi memiliki orang tua kandung (yatim piatu). Brammer (2006) menggambarkan adopsi sebagai proses di mana hubungan sah antara anak dan orang tua kandungnya terputus dan hubungan baru dibuat antara anak dan orang tua angkatnya.

Adopsi dapat dibedakan menjadi beberapa jenis berdasarkan mekanisme adopsinya serta dalam hal relasi dan komunikasi antara pihak orang tua kandung dan orang tua angkat. Williams, Sawyer, dan Wahlstrom (2007) mengemukakan bahwa berdasarkan mekanisme atau prosedur adopsinya, adopsi dapat dibedakan menjadi dua jenis, yaitu:

1) Public Adoption, merupakan jenis adopsi yang diatur melalui agen resmi berlisensi dan melalui proses hukum di pengadilan. Adopsi yang dilakukan melalui pengadilan adalah adopsi yang sah dan akan dilindungi oleh hukum. Selain itu, agen berlisensi akan memfasilitasi pengawasan terhaadap keluarga adopsi dan menyediakan layanan konseling bagi keluarga biologis maupun keluarga adopsi. Kelemahan dari jenis adopsi ini adalah prosedur pelaksanaannya yang berlangsung cukup lama. Pengawasan terhadap calon orang tua adopsi akan dilakukan minimal 6 bulan sebelum akhirnya benar-benar bisa dipastikan bahwa pasangan tersebut layak untuk mengadopsi anak tersebut.

2) Private Adoption (independent adoption), merupakan adopsi yang diatur langsung oleh orang tua biologis dan orang tua angkat tanpa adanya campur tangan pihak lain. Jenis adopsi ini hanya mengandalkan kesepakatan antara kedua belah pihak tersebut, sehingga proses adopsi dapat berjalan lebih cepat dan kedua belah pihak dapat punya kendali atau kontrol langsung atas berjalannya proses adopsi tersebut. Namun, kelemahannya adalah kemungkinan terjadinya masalah di masa yang akan datang, seperti: eksploitasi anak, pembatalan kesepakatan secara sepihak, dan permasalahan yang terjadi tidak dapat di bawa ke dalam hukum karena adopsi dengan cara ini dianggap tidak sah dan tidak dapat dilindungi secara hukum.

Adopsi mengakhiri tanggung jawab orang tua kandung terhadap anaknya dan dengan demikian adopsi bersifat permanen dan tidak dapat dibatalkan (Brammer, 2006). Ketika anak telah sah di adopsi oleh suatu keluarga, maka hukum akan melindunginya dan mempertahankan keberadaan anak yang di adopsi di dalam keluarga barunya tersebut. Dengan demikian, adopsi 
merupakan komitmen jangka panjang dan ketika anak telah di adopsi, anak tersebut dan keluarganya memiliki hak untuk menerima pelayanan dan dukungan pasca adopsi dari pihak agensi berlisensi yang bersangkutan (Save the Children, 2012).

Ter Haar dalam Kamil dan Fauzan (2008: 32) berpendapat bahwa seorang anak yang telah diangkat sebagai anak angkat, melahirkan hak-hak yuridis dan sosial baik dalam aspek hukum kewarisan, kewajiban nafkah dan perlindungan anak, perkawinan dan sosial kemasyarakatan.

Berdasarkan pandangan Ter Haar dalam Kamil dan Fauzan (2008) tersebut, selanjutnya akan dipaparkan kajian konseptual terhadap peristiwa adopsi baik berdasarkan pada aspek hukum maupun pembahasan dari segi aspek sosial sebagai lokus keberadaan profesi pekerjaan sosial dalam praktik adopsi di Indonesia.

Peristiwa adopsi dalam ilmu hukum merupakan lembaga hukum, maksudnya adalah pengangkatan anak akibatnya bernilai yuridis (Pandika, 2012). Namun, pada kenyataannya tidak semua masyarakat memahami adopsi secara utuh, sehingga private adoption atau adopsi tanpa melalui pengadilan menjadi langkah adopsi yang seringkali diambil oleh pasangan keluarga yang ingin melakukan adopsi. Masih banyak masyarakat yang pada umumnya hanya mengetahui adopsi sebagai pengangkatan anak luar menjadi anggota keluarga secara sah. Padahal public adoption merupakan adopsi yang sah di mata hukum dan status anak yang bersangkutan sebagai anak adopsi diakui oleh pemerintah. Pengetahuan masyarakat awam yang masih kurang mengenai prosedur adopsi yang benar seringkali menyebabkan status anak adopsi tidak sah di hadapan hukum (Balaati, 2013). Hal ini diakibatkan adopsi yang dilakukan tidak melalui proses hukum (pengadilan) sebagaimana seharusnya itu dilakukan. Adopsi yang tidak disahkan melalui proses hukum rawan akan permasalahan di masa yang akan datang. Jika nanti terjadi masalah dan sengketa dari kedua belah pihak, tidak akan bisa ada gugatan di pengadilan karena hak kedua belah pihak tidak dapat dituntut karena adopsi semacam ini tidak dilindungi oleh hukum (Pratiwi, 2016).

Adopsi yang tidak sesuai prosedur masih menjadi masalah yang membutuhkan perhatian lebih di Indonesia. Contoh salah satu kasus adopsi di Indonesia yang sempat ramai di media masa adalah kasus Angeline pada tahun 2015. Pada kasus tersebut, proses adopsi Angeline dinyatakan tidak sah karena tidak melalui putusan pengadilan dan belum seutuhnya memenuhi syarat sebagai calon orang tua angkat (Wahyuni, 2015) ${ }^{1}$. Apalagi dalam kasus ini

\footnotetext{
${ }^{1}$ Wahyuni, T. 2015. Kasus Angeline, KPAl Beber Cara Adopsi Anak yang Benar. Dilansir dari: https://www.cnnindonesia.com/nasional/20150612144030-12-59666/kasus-angeline-kpai-beber-cara-adopsi-anak-yang-benar
} 
salah satu dari orang tua angkat berkewarganegaraan luar negeri. Dokumen dan persyaratan yang harus dipenuhi lebih rumit dibandingkan dengan adopsi oleh sesama WNI. Kasus penganiayaan Angeline ini seharusnya menjadi trigger untuk memperkuat perlindungan anak dan memperketat peraturan yang ada terkait adopsi (Davis, 2015). Kasus ini menjadi bukti bahwa seleksi calon orang tua angkat melalui proses pengadilan penting karena tanpa adanya hukum yang menaungi, orang tua angkat dapat bersikap tidak bertanggung jawab terhadap kehidupan anak adopsi.

Selain itu, ada juga kasus adopsi di Cilincing pada tahun 2015 yang merupakan salah satu contoh private adoption. Dilansir dari liputan6. $\mathrm{com}^{2}$ dan beritasatu.com ${ }^{3}$, orang tua kandung yang memberikan anaknya untuk diadopsi tanpa melalui persidangan bahkan dapat menjadi tersangka dan mendapatkan sanksi secara hukum walaupun sudah ada kesepakatan di antara orang tua kandung dan orang tua angkat. Kedua orang tua angkat pun belum mengetahui banyak mengenai prosedur jalur resmi pengadopsian anak. Praktik adopsi ilegal dan child trafficking pun sangat rawan terjadi di Indonesia ketika bencana alam melanda. Salah satu praktik adopsi ilegal yang paling marak terjadi adalah pasca bencana tsunami Aceh pada tahun 2004 lalu.

Kasus-kasus ini menandakan bahwa proses adopsi yang baik dan sesuai prosedur resmi sangat dibutuhkan demi kepentingan terbaik anak adopsi itu sendiri. Prinsip kepentingan terbaik anak ini pun juga merupakan prinsip utama dalam praktik pelayanan dan pendampingan pekerja sosial dalam kasus adopsi. Oleh karena itu, artikel ini akan mencoba mendeskripsikan dan mengeksplorasi berbagai masalah praktik adopsi di Indonesia dan penanganannya dalam perspektif pekerja sosial.

Apabila ditinjau berdasarkan aspek sosial, kajian adopsi anak berkaitan dengan posisi anak sebagai salah satu unsur dari suatu keluarga, yang mengalami hubungan-hubungan antara pribadi yang pertama-tama dalam keluarga, misalnya hubungan anak dengan orang tuanya, anak dengan sesama anak yang lain, anak dengan anggota kerabat orang tuanya (ibu atau ayahnya). Menurut Soerjono Soekanto (1996), yang mengutip pendapat Koentjaraningrat dalam Soemitro (1990: 15):

“suatu keluarga berfungsi sebagai kelompok di mana individu itu pada dasarnya dapat menikmati bantuan dari sesamanya serta keamanan hidup dan kelompok di mana

\footnotetext{
2 Harun, M. 2015. Dinilai Salahi Prosedur Adopsi Anak, Orangtua Angkat Kecewa. Dilansir dari https://www.liputan6.com/news/read/2317794/dinilai-salahi-prosedur-adopsi-anak-orangtua-angkat-kecewa

3 Fajarta, C. R. 2015. Kasus Adopsi Bayi di Cilincing, Keluarga: Kami Berniat Mengadopsi, Bukan Membeli! Dilansir dari:

https://www.beritasatu.com/megapolitan/307180/kasus-adopsi-bayi-di-cilincing-keluarga-kami-berniat-mengadopsi-bukan-membeli
} 
individu itu, waktu ia sebagai anak-anak dan belum berdaya, mendapat asuhan dan permulaan dari pendidikannya.”

Setiap anak pada dasarnya memiliki hak dan kewajiban sebagai seorang anak dalam keluarga, tetapi kenyataannya pemenuhan hak-hak anak seringkali diabaikan, karena kondisi keluarga yang tidak memungkinkan.

Persoalan pada anak terutama dalam pemenuhan hak-haknya berkaitan erat dengan persoalan kemanusiaan, hal ini karena anak tergolong pada kelompok rentan dan anak pun masih memerlukan perlindungan dari orang tua dan negara.

Dengan jalan adopsi diharapkan anak-anak yang terlantar mendapatkan pemenuhan hak seperti yang terdapat dalam Pasal 52 ayat (1) Undang-Undang Nomor 39 Tahun 1999 Tentang Hak Asasi Manusia, yang menyebutkan bahwa setiap anak berhak atas perlindungan oleh orang tua, keluarga, masyarakat dan Negara (Abdussalam, 2007: 28)

\section{METODE}

Metode yang digunakan dalam penulisan artikel ini adalah dengan menggunakan metode studi literatur. Studi literatur adalah cara penulisan penelitian dengan mencari relevansi antara teori yang sesuai dengan isu atau permasalahan yang dikemukakan. Referensi yang digunakan dapat berasal dari buku, jurnal, artikel laporan penelitian, dan situs internet yang mumpuni.

\section{PEMBAHASAN}

Pengertian adopsi secara umum adalah suatu tindakan mengalihkan seseorang anak dari kekuasaan orang tua kandungnya ke dalam kekuasaan orang tua angkatnya, untuk dipelihara dan diperlakukan sebagai anak kandungnya sendiri, sehingga dengan sendirinya anak angkat mempunyai hak dan kedudukan yang sama seperti anak kandung (Zaini, 2002: 4)

Dengan dilakukannya pengangkatan anak (adopsi) tidak memutuskan hubungan darah antara anak dengan orang tua kandungnya. Orang tua kandung tetap memiliki hak untuk menjalankan hak dan kewajibannya sebagai orang tua kandung, oleh karena itu orang angkat wajib memberitahu kepada anak angkatnya mengenai asal usulnya dan orang tua kandungnya.

Prinsip kepentingan terbaik dalam kasus adopsi dijabarkan dalam beberapa aspek seperti mempertimbangkan kepercayaan dan latarbelakang budaya serta menjaga lingkungan keluarga. Pemberitahuan asal usul dan orang tua kandungnya dengan memperhatikan kesiapan 
anak yang bersangkutan. Pengangkatan anak merupakan wujud dari penyelenggaraan perlindungan terhadap hak anak angkat yang meliputi berbagai aspek kehidupan dengan mengacu kepada hak-hak asasi anak yang melekat padanya sejak anak itu dilahirkan, meliputi (Kamil \& Fauzan, 2010: 77):

1) Perlindungan terhadap agama.

2) Perlindungan terhadap kesehatan.

3) Perlindungan terhadap pendidikan.

4) Perlindungan terhadap hak sosial.

5) Perlindungan yang bersifat khusus/eksepsional

Di Indonesia, prinsip kepentingan terbaik buat anak juga diadopsi dalam peraturan terkait pengangkatan anak, khususnya pasal 39 ayat 1, Undang-Udang Nomor 35 Tahun 2014 Tentang Perlindungan Anak menyatakan bahwa adopsi hanya boleh dilakukan untuk kepentingan terbaik anak.

Berbagai upaya dilakukan oleh pemerintah untuk dapat mewujudkan prinsip kepentingan terbaik bagi anak dalam proses adopsi di Indonesia. Terkait hal tesebut, berikut ini akan dipaparkan berbagai ketentuan hukum dalam proses adopsi dan urgensi peran profesi pekerjaan sosial sebagai salah satu profesi yang terlibat secara langsung dalam proses adopsi di Indonesia.

\section{Prosedur dan Kebijakan Mengenai Adopsi di Indonesia}

Peraturan mengenai adopsi secara universal pertama kali terkandung pada Adoption and Children Act 2002 yang menggantikan peraturan lama pada Adoption Act 1976 (Brammer, 2006). Berbagai peraturan di Indonesia mengenai adopsi juga dibuat berdasarkan undangundang ini.

Prosedur pelaksanan adopsi di Indonesia diatur dalam berbagai peraturan perundangundangan (Balaati, 2013), antara lain: (1) Surat Edaran Mahkamah Agung RI Nomor 6 Tahun 1983 yang mengatur tentang prosedur pengadopsian anak. Peraturan ini menyatakan bahwa calon orang tua angkat harus mengurus berkas dan mengajukan permohonan ke Pengadilan Negeri di wilayah anak adopsi tersebut berada, (2) Undang-undang Nomor 23 Tahun 2002 Tentang Perlindungan Anak mengatur bahwa anak yang di adopsi harus seagama dengan orang tua angkat dan orang tua angkat tidak boleh memutus hubungan anak dengan orang tua kandungnya, (3) Peraturan Pemerintah Nomor 54 Tahun 2007 tentang Pelaksanaan Pengangkatan Anak mengatur tata cara adopsi dan menyatakan bahwa seseorang dapat 
mengangkat anak paling banyak dua kali dengan jarak waktu paling singkat dua tahun, dan (4) Berbagai prosedur adopsi anak berdasarkan hukum adat tertentu di Indonesia.

Prosedur pelaksanaan adopsi anak di Indonesia diatur dalam Undang-undang Nomor 23 Tahun 2002 Tentang Perlindungan Anak dengan peraturan pelaksana berupa Peraturan Pemerintah Nomor 54 Tahun 2007 Tentang Pelaksanaan Pengangkatan Anak yang kemudian juga dijelaskan lebih detail lagi dalam Peraturan Menteri Sosial Nomor 110 Tahun 2009 (PERMEN) Tentang Persyaratan Pengangkatan Anak. Berdasarkan ketiga peraturan tersebut dapat dirangkum syarat utama pengangkatan anak adalah sebagai berikut:

1) Syarat Kepentingan Terbaik bagi Anak

2) Syarat Tidak Memutuskan Hubungan Darah Anak Angkat

3) Syarat Orang Tua Angkat seagama dengan Anak Angkat dan Orang Tua Kandung

Adapun untuk tahap pelaksanaannya adalah sebagai berikut:

1) Tahap menyiapkan dokumen, yaitu orang tua angkat yang ingin mengajukan adopsi harus menyiapkan berkas-berkas berupa data pribadi seperti KTP, kartu keluarga, surat nikah, surat keterangan bekerja, Surat Keterangan Cakap Kelakuan (SKCK), dan sebagainya. Permohonan akan diajukan ke Dinas Sosial setempat sesuai domisili calon anak angkat.

2) Tahap uji kelayakan orang tua angkat, yaitu uji kelayakan yang akan dilakukan oleh pekerja sosial dengan melakukan kunjungan ke tempat tinggal calon orang tua angkat. Hal ini dilakukan untuk memastikan keaslian dan kesesuaian dokumen yang diajukan sebagai berkas permohonan untuk kepentingan perkembangan anak nantinya.

3) Tahap pengasuhan sementara, yaitu tahap jika calon orang tua angkat dinyatakan layak untuk melakukan pengangkatan anak, maka setelahnya akan dikeluarkan Surat Izin Pengasuhan Sementara yang akan berlangsung selama enam bulan untuk orang tua angkat melakukan pengasuhan di bawah pengawasan pekerja sosial. Orang tua angkat harus membuat laporan selama proses tersebut berlangsung.

4) Tahap rekomendasi Dinas Sosial, jika calon orang tua angkat dinilai sudah layak maka Dinas Sosial di tingkat provinsi akan mengeluarkan rekomendasi kepada Kementrian Sosial (Kemensos) dan akan diterima oleh Direktur Pelayanan Sosial Anak di Kementrian Sosial.

5) Tahap pertimbangan oleh Kemensos yaitu setelah rekomendasi diterima, maka kelayakan calon orang tua angkat akan dibahas oleh Tim Pertimbangan Perizinan 
Pengangkatan Anak (TIPPA) di Kemensos. Jika disetujui, akan dikeluarkan Surat Keputusan Menteri Sosial tentang pengangkatan anak dan jika ditolak, maka anak akan dikembalikan pada lembaga.

6) Tahap Penetapan Pengadilan, setelah menerima surat keputusan Kemensos yang menyetujui pengadopsian anak, maka calon orang tua angkat dapat mengajukan Permohonan Penetapan oleh Pengadilan Negeri untuk akhirnya adopsi tersebut disahkan secara hukum. Putusan pengadilan juga mencakup mengeni status hukum dari anak angkat dalam keluarga yang telah mengangkatnya, mengenai status hukum dari anak angkat dalam keluarga angkatnya, mengenai hak mewaris dan aturan adat dari masing-masing daerah.

Berbagai ketentuan peraturan perundangan tesebut menjadi penting untuk dipahami oleh berbagai pihak, terutama bagi mereka yang akan melakukan proses adopsi anak.

\section{Peran Pekerja Sosial Koreksional dalam Adopsi Anak}

Pekerja sosial yang terlibat dengan penanganan kasus adopsi biasanya akan menjadi anggota tim penempatan keluarga yang berpengalaman dalam pekerjaan adopsi. Sebab dalam peraturan Adoption and Children Act 2002 diwajibkan adanya ‘sejumlah orang yang memenuhi syarat, kompeten, dan berpengalaman yang cukup yang bekerja untuk keperluan layanan adopsi' (Brammer, 2006). Dalam proses adopsi, sesuai dengan perundang-undangan yang berlaku, pekerja sosial terlibat dalam semua tahapan yang ada. Pekerja sosial berperan sejak proses administratif hingga pascaadopsi. Pekerja sosial seharusnya menjadi penentu utama apakah calon orang tua angkat dan permohonan adopsinya dapat diterima dan diajukan ke pengadilan atau dianggap tidak memenuhi syarat.

Pada praktik pelayanan dan pendampingan pekerja sosial pada kasus adopsi, prinsip kepentingan terbaik anak kerap melahirkan kondisi dilematis yang dijumpai pekerja sosial. Masih dominannya kepentingan orang tua biologis maupun calon orang tua angkat - dan bukan kepentingan anak - masih menjadi realitas yang dihadapi oleh pekerja sosial. Mengangkat anak masih merupakan praktik yang didasari kepentingan calon orang tua angkat memiliki keturunan atau orang tua biologis yang karena satu dan lain hal tidak menghendaki kehadiran anak. Hal ini kerap berimplikasi pada banyak aspek, seperti: tingginya pemalsuan informasi dan dokumen serta masih sangat tingginya adopsi illegal (tidak sesuai dengan peraturan perundang-undangan yang berlaku. Pada pendampingan psikososial yang dilakukan pekerja sosial, prinsip kepentingan terbaik anak juga masih meninggalkan beberapa area yang belum tersentuh, 
misalnya minimnya intervensi yang dilakukan kepada anak yang akan atau telah diadopsi, dan juga intervensi terhadap orang tua biologis dari anak yang di adopsi (Noor \& Ro’fah, 2019: 6). Berbagai peran pekerja sosial menurut Noor \& Ro’fah (2019) dalam praktik adopsi anak adalah sebagai berikut:

1) Peran Administratif: Reinterpretasi Peraturan

Pekerja sosial bertugas memberikan pendampingan sosial dalam proses adopsi anak. (Noor \& Ro’fah, 2019) menjelaskan bahwa proses adopsi anak yang resmi dan sesuai dengan prosedur akan menghabiskan waktu tujuh hingga 10 bulan. Dalam proses tersebut, pekerja sosial terlibat di semua tahapan, diawali dengan assessment yang harus dilakukan pada visitasi awal dengan tujuan sebagai landasan penyusunan laporan sosial yang merupakan syarat adopsi.

Pekerja sosial merupakan pihak yang sangat penting dalam permohonan adopsi karena merekalah yang menjadi penentu pertama apakah sebuah permohonan bisa diteruskan ke pengadilan atau berhenti karena dianggap tidak memenuhi syarat. Sebagaimana telah dijelaskan, bahwa pekerja sosial dapat memberikan interpretasi terhadap aturan yang ada, bahkan menyesuaikan untuk tidak mengatakan mengubah peraturan untuk membantu proses adopsi. Dengan kata lain pekerja sosial memiliki “professional power” yang sangat menentukan (Noor \& Ro’fah, 2019).

Proses adopsi melibatkan beberapa langkah prosedural, kelengkapan dokumen, dan berbagai syarat administratif lainnya. Sebagaimana yang sudah dipaparkan sebelumnya, beberapa syarat tersebut antara lain seperti KTP, SKCK, dan surat permohonan adopsi. Dalam tahap ini, pekerja sosial berperan untuk melakukan asesmen dan review terhadap setiap kelengkapan administratif yang ada. Harus dipastikan tidak ada pemalsuan dokumen atau persyaratan yang tidak lengkap sebelum permohonan dapat dilanjutkan ke proses pengadilan.

2) Peran Pendampingan Psikososial Spiritual dan Pengawasan

Adopsi adalah proses hukum yang muaranya ada di pengadilan, namun proses adopsi melibatkan intervensi pekerja sosial sejak mulai assessment sampai pasca adopsi. Dalam praktiknya, dinamika kasus adopsi sangat beragam dan meniscayakan pekerja sosial untuk menjalani semua peran mulai dari manajer yang mencari pusat sumber dan menjalin kerja sama dengan berbagai stakeholder seperti dinas kependudukan catatan 
sipil (dukcapil) dan pengadilan, sampai pada pendampingan spiritual dengan menghadirkan tokoh agama.

Pentingnya konseling psikologis atau pendekatan spiritual mungkin bisa ditarik dari personalnya isu adopsi. Adopsi terjadi pada pasangan yang secara psikologis cukup rentan karena berbagai alasan: menunggu kelahiran anak bertahun tahun dan kerap mengganggu dinamika pernikahan, kerap juga terjadi keputusan adopsi yang panjang karena menunggu persetujuan semua keluarga besar. Alasan lain yang juga sering muncul adalah kelekatan yang sudah terjadi pada calon orang tua angkat dan anak angkat, sementara anak ini adalah anak tanpa identitas orang tua yang jelas (karena dibuang atau ditinggal di rumah sakit) sehingga jalur adopsi yang harus ditempuh adalah adopsi lembaga.

Proses adopsi melibatkan intervensi yang harus dilakukan oleh pekerja sosial sebagai pendamping dan pengawas calon orang tua angkat. Pekerja sosial melakukan asesmen melalui kunjungan untuk mengetahui kelayakan untuk menjadi orang tua sah dari anak yang akan diadopsi. Asesmen yang dilakukan dapat berupa visitasi, pemeriksaan latar belakang orang tua, evaluasi kehidupan rumah tangga selama ini, dan kemampuan orang tua angkat untuk memenuhi kebutuhan-kebutuhan khusus anak adopsi. Pengawasan dan asesmen dilakukan dengan tujuan memastikan kecocokan antara anak dan calon orang tua angkat.

Selain pengawasan, ada juga peran pendampingan yang harus dipenuhi oleh pekerja sosial. Pendampingan dilakukan dengan tujuan untuk memberikan pelayanan pemberdayaan bagi calon orang tua angkat agar mereka menjadi orang tua yang baik untuk kebutuhan dan kepentingan anak yang akan mereka adopsi. Pelayanan yang diberikan dapat berupa konseling dan edukasi kepada calon orang tua angkat.

3) Peran Mediator dan Broker

Dalam proses adopsi anak, pendampingan psikososial tidak hanya dilakukan ke calon orang tua angkat, tetapi juga kepada orang tua kandung dan keluarga besar kedua pihak. Dalam proses adopsi kadang juga terjadi konflik antarpihak yang terlibat. Biasanya yang terjadi kadang terjadi penolakan dari keluarga besar calon orang tua angkat atau orang tua kandung atau konflik antara calon orang tua angkat dan orang tua kandung.

Dengan demikian, pekerja sosial juga berperan sebagai mediator antara orang tua angkat dan orang tua kandung (jika masih ada) sekaligus menyediakan layanan 
konseling bagi kedua belah pihak agar terdapat komunikasi yang baik antara kedua belah pihak untuk menjaga terjalinnya relasi yang baik di masa yang akan datang. Selain itu, pemerintah atau lembaga yang bersangkutan seharusnya memberikan pengawasan dan bimbingan yang baik bagi pasangan calon orang tua angkat ketika akan melakukan adopsi anak.

Komunikasi yang baik diperlukan oleh kedua belah pihak agar proses adopsi dapat berjalan dengan baik sampai akhir. Selain itu, di masa mendatang ada baiknya juga relasi yang baik juga tetap terjalin diantara anak dan orang tua kandung mereka. Pelayanan yanng dapat diberikan antara lain berupa layanan konseling bagi kedua belah pihak, mempertemukan kedua belah pihak untuk saling berkomunikasi dan berdiskusi terkait kepentingan terbaik anak, dan memediasi komunikasi antara anak dan orang tua kandung jika diperlukan, misalnya dengan cara letterbox atau surat-menyurat sebelum akhirnya dapat melakukan direct contact (Featherstine, Gupta, \& Mills, 2018).

Selain itu, pekerja sosial juga berperan sebagai broker, yaitu sebagai perantara untuk menghubungkan klien dengan lembaga-lembaga, pihak berwenang, dan pemerintah untuk memudahkan aksesibilitas dan keefektivan pelayanan yang diberikan.

4) Peran Advokasi

Tidak semua orang tua angkat melakukan adopsi sesuai prosedur hukum yang berlaku. Seperti pada kasus Angelina atau kasus child trafficking pasca bencana, misalnya. Jika kasus demikian sudah terjadi, pekerja sosial berperan sebagai advokat untuk dapat memperjuangkan hak-hak, perlindungan, dan pemenuhan kebutuhan anak angkat.

\section{SIMPULAN DAN SARAN}

Adopsi merupakan salah satu upaya yang dilakukan pasangan suami istri untuk dapat memiliki kehadiran sosok anak di keluarga mereka, sekaligus menjadi penerus keluarga mereka ke depannya. Adopsi di Indonesia telah memiliki peraturan mengenai prosedur dan perlindungannya secara hukum dan diatur dalam beberapa undang-undang dan ketetapan pemerintah yang berlaku. Namun dalam pelaksanaannya, ada berbagai permasalahan terkait dengan adopsi di Indonesia, antara lain kurangnya pemahaman dan pengetahuan masyarakat akan adanya prosedur pelaksanaan adopsi yang sah secara hukum, tidak adanya data valid 
mengenai jumlah adopsi di Indonesia, dan masih terjadinya sengketa antara orang tua angkat dan orang tua kandung akibat prosedur adopsi yang dilakukan secara private adoption.

Pekerjaan sosial merupakan salah satu profesi yang memegang peran yang sangat penting dalam proses adopsi anak. Peran pekerja sosial mulai dari peran administratif, peran pendampingan sosial sampai sebagai mediator. Pekerja sosial memegang peran kunci dalam keberlanjutan sebuah proses adopsi yang sesuai dengan prosedur dan undang-undang dan juga sesuai dengan tatanan sosial masyarakat. Oleh karena itu, perlu ada penguatan kapasitas bagi pekerja sosial untuk mendukung peran dan fungsi yang dijalankannya

Berdasarkan hal tersebut, maka rekomendasi atau saran yang bisa diberikan terkait permasalahan adopsi di Indonesia antara lain sebagai berikut:

1) Perlu adanya sosialisasi publik yang lebih baik dari pemerintah terkait prosedur pengangkatan anak kepada masyarakat. Pemerintah juga perlu menghimbau masyarakat untuk melakukan adopsi secara sah melalui pengadilan dan sebisa mungkin meminimalisasi private adoption.

2) Seperti di Amerika Serikat, pemerintah mungkin dapat membuat suatu lembaga seperti AFCARS untuk memudahkan pengumpulan data mengenai peristiwa adopsi, sehingga ada data dan jumlah yang valid terkait dengan adopsi.

3) Perlu disatukannya aturan mengenai pengangkatan anak di Indonesia melalui pembuatan undang-undang agar peraturannya tidak terlalu beragam. Misalnya, panti asuhan atau lembaga yang bersangkutan hanya akan memfasilitasi saja dan tidak boleh melakukan pengajuan adopsi melalui lembaga atau yayasan karena sebenarnya mereka tidak berwenang melakukan pengajuan adopsi. Kemudian segala pengajuan permohonan adopsi mungkin dapat dilakukan melalui satu pihak saja. Untuk pasangan WNI-WNI hanya melalui Dinas Sosial setempat dan untuk WNI-WNA hanya melalui Kementrian Sosial agar memudahkan berjalannya proses adopsi dan data adopsi yang masuk ke negara.

4) Pemerintah perlu melakukan pengembangan dan evaluasi rutin terkait pengawasan dan bimbingan kepada calon orang tua angkat untuk membekali mereka agar memperhatian kesejahteraan dan menempatkan upaya untuk memenuhi kepentingan yang terbaik untuk anak dapat terjamin dengan baik.

\section{DAFTAR PUSTAKA}

Abdussalam (2007). Hukum Perlindungan Anak. Jakarta: Restu Agung. 
Alfaizi, M. D. S. (2016) Pengangkatan Anak (Studi di Masyarakat Duren Tiga). SKRIPSI. Universitas Islam Negeri Syarif Hidayatullah.

Bachelard, M. (2013). Thousands of Babies sold on Indonesian Black Market. Dilansir dari https://www.smh.com.au/world/thousands-of-babies-sold-on-indonesian-blackmarket-20130511-2jeaj.html

Bakhtiar, H. S. \& Yustiana. (2017). Legal Arrangements Regarding the Adoption of Children in Indonesia. International Journal of Humanities and Social Science Invention (ISSN) $6(2): 33-44$.

Balaati, D. (2013). Prosedur dan Penetapan Anak Angkat di Indonesia. Jurnal Lex Privatum 1(1):138-145.

BBC News Indonesia. (2018). Adopsi Anak Ilegal dari Indonesia dan Negara Lain: Belanda Lancarkan Penyelidikan. Dilansir dari https://www.bbc.com/indonesia/majalah46477797.

Brammer, A. (2006). Social Work Law. US: Prentice Hall/Pearson Education Ltd.

Fahrudin, A. (2010). Advokasi Pekerjaan Sosial. STKS Bandung. Diunduh melalui https://www.researchgate.net/publication/308985836_ADVOKASI_PEKERJAAN_S OSIAL/link/5b4851c5a6fdccadaec42d80/download.

Family Equality Council. (2019). Every Child Deserves a Family. Diunduh dari https://everychilddeservesafamily.com/

Hoffman, Lois W. \& Manis, Jean D. (1979). “The Value of Choldren in the United States: A New Approach to the Study of Fertility”. Journal of Marriage and the Family. 41. 583596.

Hotz, Robert Lee. (2008). “Some Scientists Argue We Are Built to Coo at the Sight of a Baby”. Wall Street Journal. Cl.

Kamil, A. \& Fauzan H. M. (2010). Hukum Perlindungan dan Pengangkatan Anak di Indonesia. Cet. 2. Jakarta: PT Rajawali Grafindo Persada

Kringelbach, Morten L. et al. (2008). “A Specific and Rapid Neural Signature for Parental Instinct”. PLoCONE. 3 (2), 
Noor, Nina Mariani \& Ro’fah. (2019). Praktik Adopsi Anak dan Peran Pekerja Sosial Dalam Proses Adopsi Anak Di Daerah Istimewa Yogyakarta. Jurnal PKS Vol. 1 No. 1. Hal. 117

Olson, D. H. L. \& DeFrain, J. D. (2006). Marriages and Families: Intimacy, Diversity, and Strengths (5th ed.). New York: McGraw-Hill Companies, Inc.

Pandika, R. (2012). Hukum Pengangkatan Anak. Jakarta: Sinar Grafika.

Pratiwi, I. P. (2016). Akibat Hukum Pengangkatan Anak yang Tidak Melalui Penetapan Pengadilan. Jurnal Magister Ilmu Hukum dan Kenotariaan Universitas Brawijaya. Diunduh

dari http://hukum.studentjournal.ub.ac.id/index.php/hukum/article/view/1691.

Santoso, M. B., Apsari, N. C. \& Taftazani, B. M. (2018). The Involvement of Parents in the Children's Care Process; A Comparison of Various Countries. EMPATI Jurnal Ilmu Kesejahteraan Sosial. Vol. 7 No. 1 Juni

Save the Children. (2012). Intercountry Adoption. Policy Brief. Diunduh dari http://resourcecentre.savethechildren.se/node/6250.

Soekanto, Soejono. (1996)Pengantar Penelitian Hukum. Jakarta: Universitas Indonesia

Soemitro, Irma Setyowati. (1990). Aspek Hukum Perlindungan Anak. Jakarta: Bumi Aksara

Undang-Udang Nomor 35 Tahun 2014 Tentang Perlindungan Anak

Williams, B. K., Sawyer, S. C., \& Wahlstrom, C. M. (2006). Marriages, Families, \& Intimater Relationship: A Practical Introduction. Boston: Pearson Education, Inc.

Zaini, Muderis. (2002). Adopsi Suatu Tinjauan dari Tiga Sistem Hukum. Jakarta: Bina Aksara

Zuhra, W. U. N. (2016). Adopsi Internasional yang Tak Lagi Diminati. Dilansir dari https://tirto.id/adopsi-internasional-yang-tak-lagi-diminati-bDTB. 